\title{
Translation and Reception of The Wealth of Nations by Spanish and Latin American Authors during Eighteenth and Nineteenth Centuries
}

\author{
Paz Molero Hernández \\ Villanueva University Center, Complutense University of Madrid, Madrid, Spain \\ Email: pmolero@villanueva.edu
}

Received 31 March 2015; accepted 3 May 2015; published 8 May 2015

Copyright (C) 2015 by author and Scientific Research Publishing Inc.

This work is licensed under the Creative Commons Attribution International License (CC BY).

http://creativecommons.org/licenses/by/4.0/

(c) (i) Open Access

\begin{abstract}
The objective of this paper is not the complete work, but namely to analyze the reasons for which in Spain and Latin America The Wealth of Nations, was censored in the eighteenth and nineteenth centuries and to analyze in turn whether the reasons for this censorship correspond to the ideas that Adam Smith effectively defended. It is not intended to judge the intention of any of the parties involved in this process but to understand the context in which they occurred, and to judge whether people in Spanish-speaking countries during those centuries knew what Adam Smith actually wanted to express.
\end{abstract}

\section{Keywords}

Adam Smith, Censorship, Spain and Latin America Eighteenth and Nineteenth Centuries, The Wealth of Nations, Scottish Enlightenment

\section{Introduction}

Adam Smith remains topical. The man considered to be the father of modern economics is quoted frequently in speeches of all kinds, in many such occasions being recognized for concepts that presuppose ideas he did not define or that he simply outlined. This is the reason why this paper hopes to study a concept that is not well known and is partial, at the same time that resulted from his work, knowing full well that a complete understanding of his intentions or of the intellection of his thought is not possible.

How to cite this paper: Molero Hernández, P. (2015) Translation and Reception of The Wealth of Nations by Spanish and Latin American Authors during Eighteenth and Nineteenth Centuries. Open Journal of Social Sciences, 3, 46-57. 
The work that was considered his masterpiece was The Wealth of Nations ${ }^{1}$ [1], which was written in 1776. It became a milestone in the history of economic thought. Suffice it to think about the condemnation that he makes in it of mercantilism, his apology for parsimony as the budget for accumulation of capital, the manner in which he judges unproductive labor or the treatise that he writes on the division of labor.

The objective of this paper is not the complete work, but namely to analyze the reasons for which in Spain and Latin America The Wealth of Nations, was censored in the eighteenth and nineteenth centuries as well as analyzing whether the reasons for this censorship correspond to the ideas that were effectively defended by Adam Smith (hereinafter AS). My focus is on the translation of this work into Spanish in those centuries, since it is the first known work by the author and it is translated into Spanish; it will also have censorship cuts for various reasons which we will analyze later. The Theory of Moral Sentiments, although it is prior, was to be released in its full version in Spanish in the late twentieth century and fewer things will be known in the two centuries that are the subject of this investigation $[2]^{2}$.

The Spanish version would have to wait until the beginning of the last decade of the eighteenth century. José Alonso Ortiz, lawyer added to the Royal Council and Chancellery of Valladolid, initiates at that time the long journey that would separate the Spanish translation of The Wealth of Nations from the printing house and public dissemination. Thanks to Alonso Ortiz's skill against the censors and thanks also to the payment of the high cost of some mutilations in the text, the authorization to print The Wealth of Nations in the workshops of the Viuda e Hijos de Santander, published in Valladolid, in four volumes in 1794, could be obtained [3].

I do not intend, however, to judge the intentions of any of the parties involved in this process. It is important in this type of analysis to understand the context in which the events took place. If a complete understanding is not possible, my intention is that, at least, it may be sufficient. For this reason, in the beginning of this paper, pointers are given about the time period in which AS writes his work. In order to do this, it is necessary to position AS within the controversy that had been developing in Britain, particularly in Scotland, both in the field of scientific research and in the discussion about human nature. At the same time we must understand the Scottish Enlightenment, within which AS is formed, as an intellectual center where discussions take place on topics of psychology, moral theology and ascetics. In his time, the foundation of economic activity is redefined and not put anymore in the possession of the land but rather in interpersonal relationships whereby the social fabric, as the reference, becomes more important. The strength of the economy is considered, in turn, the stamp of a well established and orderly society.

Then, I deal with the historical context of the Spain of that time, to go on to explain the reasons that may have lead to censor the work in its Spanish translation, to analyze whether it is properly understood by the censors and, therefore, what interpretation of A. Smith Spanish speaking countries of the eighteenth and nineteenth century have inherited. I end with a few conclusions about whether Catholic tradition, the majority religion in these countries, truly understood, in my opinion, what AS meant.

\section{The Wealth of Nations and Its Time Period}

Arguably, The Wealth of Nations is largely a product of its time. Without intending with this statement to be detrimental to the author, he became part of the Scottish school of Moral Philosophy from which he takes his method of social research. Without these influences, it probably could not have been written or the end result would have been very different. Adam Smith had the wisdom to capture well the ideas and economic problems of the society of his time to assess and draw conclusions. Science is not aseptic, scientists, as well as men in general, are affected by the historical moment in which their ideas are developed.

Thus, AS is not indifferent to the time in which he lives and writes the WN. The underlying approach that follows, according to the Scottish school, can be summarized in a certain psychologistic reductionism, of social behavior and human institutions, a usage of historical data as a fundamental part of the research program and a rigorous methodology, through experimentation and observation.

It is also the moment of the inception of the Bank of England, of public debt, of parliamentary sponsorship, of the professional army and of a social class that with its income, for its own benefit, maintained the previous two institutions. These changes result in the British awareness for economic matters moving to the foreground. The world, according to some, is a game of appetites and irrationality. The independence of personal property in real

\footnotetext{
${ }^{1}$ The quotes of this work como from this edition. Henceforth WN.

${ }^{2}$ Henceforth TMS.
} 
estate also causes the individual to lose his bearings, to find it more difficult to build ties to his origin, his homeland and to be more exposed to consumer appetite.

The social philosophy that emerges in Scotland, in the time before the WN, is originated from a treatment of human passions. Thus, the pre-eminence of the passionate in the constitution of society is supportive of the debate about human nature, prompted in part by neostoic and neoplatonic doctrines, and above all by the rise of anthropological doctrines that took as their basis the depravity of man [4].

Articulating all of these scattered ideas in the speculative and practical tradition that preceded Smith depended upon a deep knowledge of them, while also requiring time to articulate them in a coherent system and entailed, finally, to capture that construction in a style and manner that made them reachable and acceptable to society. AS met all these requirements ${ }^{3}$.

The WN is considered to be his masterpiece. In the first four books, AS describes the benefits of a liberal approach to equality, freedom and justice and explains the obstacles that mercantilism conceals, which have affected England and other countries. In Book V he presents an analysis of the role of the state in his liberal approach and discusses some consequences of the manner of implementing the role of the ruler with which he does not basically agree. The overall objective of this work, as he declares, is to promote political discussion and encourage the seeking of ways to promote the happiness of society. The work however will mature slowly as it took 10 years to write. At Smith's death, which occurred on July 17, 1790, fourteen years after the appearance of The Wealth of Nations, the fame of his figure and the value of his work were already recognized and widespread in the world of his time.

\section{Spain in the Time Period of The Wealth of Nations}

Although most Spanish writers of the eighteenth century, unlike the French philosophers, respected religion and the monarchy, after the French revolutionary events of 1789 there was some fear in Spain that some of the revolutionary ideas could lead to similar incidents. The powerful minister of Charles III, Floridablanca, was one of those who shared that fear and from the power he tried to cordon off the peninsula so that what had happened in France would not extend. The civil and inquisitorial power united against a common enemy: the French revolutionaries, who questioned the power of absolute monarchy and of the Catholic Church. However, after the fall of Floridablanca, in 1792, his substitutes, first Aranda followed by Godoy, agreed to suggest more opening measures like those that abolished the prohibition of periodical press action. The opening was reflected in the translations that were made in the last decade of this century. Texts from Condillac, Genovesi, Hume, Turgot, Quesnay and, of course, Smith, were translated.

All these facts are obscured by others, such as the prohibition of the chairs of public law and natural law and of nations in 1794. And although we must balance the favorable facts with the unfavorable ones, we can conclude that in the early years of the Godoy in power, there was some revival of the Enlightenment. In this resurgence, which some may describe as modest and in which there was no freedom of speech, translations by A. Smith were published by Martinez de Irujo and Jose Alonso Ortiz.

It can also help to frame the issue at hand that freedom of speech, during the eighteenth century, was limited both by the civil power and by the Inquisition, an institution that had seen its power decimated during the reign of Charles III and had been subdued to civil power. Prior censorship of the Council of Castile was needed to obtain a license to print, and the more conservative members of the Council did not give licenses to publications that were considered suspicious or dangerous. Therefore, it is no wonder that translators devoted their works to these powerful ministers, both to have no problem with civil censorship, as well as to promote themselves in the state's administration [5].

The Inquisition had lost power to the state though it was still an institution that commanded respect. Translations did not only make a work that could not be read in a foreign language available to the public, but also al-

\footnotetext{
${ }^{3}$ Thanks to TMS's success he is invited, as the personal tutor of the Duke of Buccleugh, to tour Europe. Starting from January 1764, Smith travels through Europe, living in Paris a year (first two months and ten later), eighteen months in Toulouse and two months in Geneva. This trip definitely increases Smith's economic literacy, since it takes place in the developing phase of the "Nouvelle École des Économistes", with whose components Smith kept direct and intense relationships. In the summer of 1764 Smith wrote to Hume from France telling him that he was bored, and that to pass the time he had started writing a book (cf. Correspondence of Adam Smith (1987) Liberty Press, Indianapolis, 82, 102), probably the root of his WN.

On his return to England, in early November of 1766, Smith moved to London, working with Charles Towshend for six months. He stays in London until the wedding of his pupil, in May 1767. That's when Smith decides to capitalize for the political economy the generous retirement his pupil had set for him by fixing an annual pension for him. He published the first edition of WN in 1776.
} 
lowed the censorship of those observations that were ungodly, heretical or harmful to the Spanish political system, which would have caused the ban of the original work by the Inquisition or the Royal Censor, and allowing, in this way, the Spanish reader to access the works that would have been otherwise unattainable or dangerous to own. However, on many occasions, and in the present one it was so, to pass the step of the civil censorship was more important than that of the Church.

\section{Translation and Dissemination of The Wealth of Nations in Spain and the Spanish-Speaking World in the Eighteenth and Nineteenth Century}

In 1792 the Spanish Inquisition (the apostolic Inquisitors against heretical depravity and apostasy) issues an edict banning the book in its French version [6]. In Spain at that time the precautions to prevent the spread of revolutionary ideas in this country intensified and steps were taken with more prevention, if possible, against everything that had that origin. The book could not be read under penalty of excomunion unless one had a license and "this to find flattering content of the religious tolerance and to induce naturalism" [7].

The first translation into Spanish of the WN is the one by Luis Alonso Ortiz in 1794. Until then there was only a partial translation of the abstract or Compendium of Condorcet, written by Martínez de Irujo. It is interesting that after what has been mentioned about censorship, Martinez de Irujo managed to save his translation. But "undoubtedly the prudence of the translator also contributed to the publication of the translation. First of all, he never mentions the name of Smith and rectifies some points that could disturb. The translator notes that Condorcet in the Compendium had eliminated those improper implications of the original work, but contained the author's basic principles in matters of economic growth”.

In 1794, the Office of the Widow and Children of Santander published in Valladolid the first translation of the English original of the eighth edition. Alonso Ortiz made some modifications to the work, so that it would pass both ecclesiastical and civil censorship on issues relating to education, tithes, usury, unfavorable references to Spain and to the Catholic religion. The second edition of this "very corrected and improved" translation appears that, it too, was made by Ortiz and published in 1805-1806 in Valladolid, by the press Office of the Widow and Children of Santander, in four volumes.

The authorization process for this translation was not easy. Ortiz does not appear to be very optimistic about the functioning of the Holy Office, since, simultaneously and at his own risk, he sought permission of the Royal Council of Castile to publish the work with the notion that this high body would authorize it, as it had already done with the Compendium with the WN by Martínez de lrujo. But the Royal Council of Castile was not calm about it, and wanted advice from the Royal Academy of History, to which it sent Ortiz's work for censorship. The three censors of the Academy did not believe there to be any basis for prohibition, but nevertheless, the translation remained pending of the inquisitorial ruling.

Things were going more slowly in the Supreme Council of the Inquisition. Not satisfied its components with the opinion of two qualifiers, in the sense that Ortiz's translation included the errors of the French text, a new court, which included the friar who intervened in condemning the French text, was appointed. The outlook thus opened then for the appearance of the WN, in Spanish, did not look to be very promising. Incomprehensibly, however, the ineffable condemning friar did not last even two months in court, being replaced by another religious, and luck seemed to straighten out in favor of the Spanish translation of the WN. After some corrections that the board members indicated to Ortiz, the manuscript was given back and the work went public in 1794, after government approval. Alonso Ortiz added in his version a multitude of notes and comments, sometimes truly interesting, and on various issues he openly disagreed with the opinions of Adam Smith [8].

Pedro Schwartz has done a thorough job which highlights the most important deletions, corrections, additions, notes and other modifications made by the translator:

The preliminary note in which Smith is praised for trying to reduce the economic issues to a scientific method or general system.

Most important he added appendices: the Table of the prices of wheat and barley in the land of Castile, the Appendix on the Spanish National Bank of San Carlos. Such appendages serve the function of clearing things up about the history of the Spanish economic history and its institutions explained by the translator.

An important addition is the index of the work arranged by the series of its books and chapters, with a summary in the same order as that of the main subjects of its context.

Amendments to the text to satisfy the civil and ecclesiastical censors: the paragraphs dealing with the Catholic religion, education, tithing, usury and those that attack the monarchs of Spain. 
Numerous notes that took him many hours of work and contributed to clarify some Smithian ideas, to disagree with the thinking of the Scottish writer or sweeten some suspicious ideas. The notes get it right when dealing with monetary matters and some errors that escape them can be explained by poor explanations by Smith. More noticeable are Ortiz's errors when he stops in price theory or when speaking about international trade [9].

After that, until 1806, there are only two editions of The Wealth in Spanish and the synthesis published in 1792. From 1806-1933 no editing of Smith's masterpiece is performed. This is because Say and Bastiat were the authors who were the most translated and read by the Spanish in the nineteenth century ${ }^{4}$. It seems then that AS was read more by the illustrated than by the nineteenth century Spanish liberals. By the dates of publication of the translations of The Wealth, we can affirm that said work was read in Spain before the publication of Say's Treaty. Therefore, it was primarily the last generation of enlightened that read Smith ${ }^{5}$. In particular, we know that the ones who were most influenced by it were Gaspar Melchor de Jovellanos, Vicente Alcalá Galiano and Luis Alonso Ortiz, however, these authors sometimes fall into serious contradictions with the Scottish thinker [10].

In 1807 the subject of political economy was introduced as a discipline in the curricula of Spanish universities, although during the absolutist decade (from 1823-1833) it was removed because it was considered to be a dangerous discipline. The problem that arises then is finding the appropriate manuals. To start, foreign texts were used. Between 1776 and 1806 Smith and Genovesi were recommended. But Smith was immediately replaced by Say [11].

"In view of the foregoing information, the monographic about the consulted Spanish economists, it seems appropriate to maintain that the influence of The Wealth of Nations in Spain was not important. Smith might be a symbol to free traders and the father of economics for teachers, but the Wealth was not really read or translated that much if compared to Say and Bastiat. The latest generation of enlightened, who were the ones who read the most by Smith, did not take from this author the arguments for free trade both domestic and with the colonies, nor the idea of the importance of establishing good economic institutions in order to achieve greater economic growth, nor all of the ideas presented in the debate on the reform of the IRS. There were many enlightened and economists of the nineteenth century such as Valle Santoro who departed from the Smithian propositions where they were applied to Spain” [12].

Smith's ideas in the nineteenth century were known not through direct reading of The Wealth, but through Say's numerous translated works. The inclusion in the Index of the French edition could have stigmatized the WN book between predominantly Catholic countries, to which we must add that the economy the Spanish learned in the manuals written by their countrymen was an eclectic economy, obtained from numerous authors.

The final conclusion that can be deducted after seeing the dates that mediate between the translation by Alonso Ortiz and the next is that the liberal politicians of the nineteenth century, who were more rhetorical than theoretical, preferred other arguments to Smith's to defend free trade and anti interventionist policies. Specifically they preferred Bastiat, Mirabeau, and Say, who enjoyed therefore more success than Smith amongst the Spanish economists [13].

\section{Analysis of the Reasons for the Self-Censorship and Adaptation of the Traslation by Ortiz}

As already mentioned, the translation by Ortiz is, basically, an adaptation of the WN since it comments, cuts or deletes considerable parts of the original text, especially, from books IV and V. The reasons are varied, some are civil or historical, others are religious. Most Spanish economists of Ortiz's era defended the Catholic religion, the absolute monarchy and the homeland, however, they could criticize the economic situation. Having to pass the civil and ecclesiastical censure led them, sometimes, to self-censor their explanation for fear of being censored, which is the case of Alonso Ortiz.

\subsection{Portrayal of Spain and Its Colonies in the WN}

The Scottish economist expands for numerous pages in the explanation of the historical event of the discovery of

\footnotetext{
${ }^{4}$ Say was translated because he wrote one of the key books to provide the teachings of political economy in Spain and Bastiat because he was an author who clearly, although superficially, explained pro-free trade arguments. The cause of the success of Say's books lies in their being more suitable than the WN for teaching (it also should not be forgotten that the Spaniards of the time read more easily French than English). The French economist surpasses the English one in clarity, order and lightness of the text.

${ }^{5}$ Until 1956 there will not be a complete and accurate translation of The Wealth of Nations in Spain. It is the translation undertaken by Amando Lázaro Ros who carried out the first accurate and complete translation to Spanish WN (Aguilar, Madrid).
} 
America and the reasons that led the Spaniards to conquer and colonize these new lands. The bottom line amounts to saying that the discovery and subsequent conquest was based on the thirst for gold.

"From the information of Columbus, the Council of Castile decided to take possession of some countries whose inhabitants were clearly incapable of defending themselves. The pious purpose of converting them to Christianity sanctified an unfair project, whose sole aim was the hope of finding gold" [14].

AS continues by saying that the Spaniards did not realize, nor did any of the countries that undertook discoveries in general, that the advantage was not in metals but on expanding the market and, consequently, increasing their productivity and the division of work. Later on he will declare that in Spain the feudal system has been abolished but has not been replaced by a better system and therefore, the thirst for gold that drove the undertaking of the discovery had squandered the advantages that the market expansion entailed. He thinks that the policy prohibiting the removal of metals has hindered the development of productive sectors in Spain.

"But that the monopoly of the trade of populous and thriving colonies is not alone sufficient to establish, or even to maintain, manufactures in any country, the examples of Spain and Portugal sufficiently demonstrate. Spain and Portugal were manufacturing countries before they had any considerable colonies. Since they had the richest and most fertile in the world, they have both ceased to be so. In Spain and Portugal, the bad effects of the monopoly, aggravated by other causes, have, perhaps, nearly overbalanced the natural good effects of the colony trade. These causes seem to be other monopolies of different kinds: the degradation of the value of gold and silver below what it is in most other countries; the exclusion from foreign markets by improper taxes upon exportation, and the narrowing of the home market, by still more improper taxes upon the transportation of goods from one part of the country to another; but above all, that irregular and partial administration of justice which often protects the rich and powerful debtor from the pursuit of his injured creditor, and which makes the industrious part of the nation afraid to prepare goods for the consumption of those haughty and great men, to whom they dare not refuse to sell upon credit, and from whom they are altogether uncertain of repayment. In England, on the contrary, the natural good effects of the colony trade, assisted by other causes, have in a great measure conquered the bad effects of the monopoly" [15].

That is, having previously said that the advantage of conquering some colonies does not lie in obtaining precious metals, but on the market expansion, now he will insist that the monopoly will benefit a section of the businessmen but not the entire population. Spanish economists had reached the same conclusion, the difference, however, is that the latter give a sweetened vision of Spain. Smith's patriotism allowed him to freely criticize the shortcomings of its political system since England enjoyed greater freedom of speech. He also had no problem talking about usury or about the conduct of the monarchs. Inquisitorial censors resented this freedom.

It is true that AS may be excesive in his criticism of Spain and its institutions but it is also true that he acts in similar fashion when it comes to those aspects that he considers negative about his country. To him, the logic behind the mercantilist system reflects the fetishism surrounding money in society, the popular belief that being rich is having money and that having wealth and having money are synonymous. In essence, despite the critical comments from Book IV, which is where the fundamental criticisms of Spain are found, it is a detailed complaint to the harmful effects that result from the ties with the feudal system. "The main point is the Smithian conviction that a monopoly is a privilege of the producers in contrast with the interests of the community" [16]. This book is also where Smith analyzes the popular notion that confuses the notions of wealth and money [17]. The assumption that a country "is generally rich in the same way as a person" [18] is a serious error. Indeed, according to Smith, the cause of wealth for a nation is not the quantity of gold and silver that it accumulates, but its work.

\subsection{Criticism of the Church of Rome and Religions in WN Religious Tolerance}

This point, if anything, is more complex than the previous one because in it is not just about historical facts, even if it is about that too, but the way in which it is understood that AS criticizes the religion and particularly the Papacy. The times when AS addresses this issue (Book V, Section I of the WN) will be the most cut out in Alonso Ortiz's translation.

Throughout book V, when dealing with the revenue of the government or of the royal family, AS deals with the problem of how to finance institutions aimed at educating society. There he establishes a noticeable difference between the education that the poor and the members of the upper classes must receive, all largely derived from his concept of benevolence and self-interest.

For AS, the education system can be made accessible to most through schools depending on parishes or dis- 
tricts paying a moderate rate. The state obtains a great advantage from instructing the poorer classes because it frees them of the fanaticism and the superstition that could be the cause of great disorders. The study might awaken interests that activate worse passions in the rich but even his becoming a monster would also be beneficial to society. The obstacle for the poor would be basic education and the abundance of work, for the rich the obstacle is indicated by the law. It is precisely here that he talks about religious intolerance. Defrayed religious education, turn to indifference, the clerics and teachers who become intolerant of other faiths in order not to lose the fees that they already have established.

It is worth it, despite its size, to restate the quote since it does not seem to be an attack to the essence of the creeds but rather a criticism of the defect of a particular system. It is a passage where he is making a reference to the fact that the institutions intended for education are mainly the ones concerned with religious education. Teachers are completely dependent for their livelihood either on voluntary contributions or, on some other fund, that the laws of their country assigns to them:

"Their exertion, their zeal and industry, are likely to be much greater in the former situation than in the latter. In this respect, the teachers of a new religion have always had a considerable advantage in attacking those ancient and established systems, of which the clergy, reposing themselves upon their benefices, had neglected to keep up the fervour of faith and devotion in the great body of the people; and having given themselves up to indolence, were become altogether incapable of making any vigorous exertion in defence even of their own establishment. The clergy of an established and well endowed religion frequently become men of learning and elegance, who possess all the virtues of gentlemen, or which can recommend them to the esteem of gentlemen; but they are apt gradually to lose the qualities, both good and bad, which gave them authority and influence with the inferior ranks of people, and which had perhaps been the original causes of the success and establishment of their religion. Such a clergy, when attacked by a set of popular and bold, though perhaps stupid and ignorant enthusiasts, feel themselves as perfectly defenceless as the indolent (...) Such a clergy, upon such an emergency, have commonly no other resource than to call upon the civil magistrate to persecute, destroy, or drive out their adversaries, as disturbers of the public peace. It was thus that the Roman catholic clergy called upon the civil magistrate to persecute the protestants, and the Church of England to persecute the dissenters; and that in general every religious sect, when it has once enjoyed, for a century or two, the security of a legal establishment, has found itself incapable of making any vigorous defence against any new sect which chose to attack its doctrine or discipline. Upon such occasions, the advantage, in point of learning and good writing, may sometimes be on the side of the established church. (...) In the church of Rome the industry and zeal of the inferior clergy are kept more alive by the powerful motive of self-interest, than perhaps in any established protestant church” [19].

To avoid these defects, AS ends up postulating a church independent from government power. He is ahead of his time defending a separation between church and state, that is, that there be no denominational states or established churches [20].

The religious wars had threatened the social and political stability of the various European nations and religion had become a powerful weapon to undermine peace and social harmony. AS blames politics for having gotten to partnerships with some of the great religions, and for having embraced dogmas from those with which it was allied, limiting the freedom of its subjects. "Times of violent religious controversy have generally been times of equally violent political faction” [21].

In the pre-Reformation Europe, men who took religion seriously had sought safety in it, not in the power of the king, but in the supernatural power that was represented by religion, without rejecting the king's protection. One thing was to lose material property, be it more or less important, and another thing was to lose the soul. It was worth nothing for a man to gain the world if he lost his soul. Property, while being important, was not the most important thing. The religion instituted in the visible form of the Church was the repository of the means which enabled this protection of the soul. The bloody history of religious wars would not only have motivated Hobbes to look for a system that would preserve peace, but in some way it is also present in the thinking of Adam Smith. For him a society with two hundred, three hundred or thousands of different sects constitutes the best option.

Certainly the Churches of Luther and of England were less politically contentious, as they accepted that the sovereigns would have the episcopacies becoming the true heads of these churches and so, for AS, they were from the beginning favorable to peace. He knows that for centuries religion has played the role that he wants to give to the political power [22].

AS does not understand the Catholic religion and reduces it to a superstition that, according to him, has nur- 
tured the private interests of a clergy that for centuries enjoyed rank and fortune and had the backing of political power. He largely makes this judgment because the analysis that he does of the Church of Rome uses, as if it were a case proven over time, the historical situation of the Church in the early Middle Ages [23]. For AS, Catholicism had always shown a preference for the poor, but when the clergy and nobles were carried away by the eagerness of ownership and vanity the power of the Church declined throughout Europe because its authority was greatly weakened [24]. He considers that a religion so understood has great reception among the slaves and the savages. After this analysis, AS continues and forecasts that Catholicism in the course of a few more centuries, will disintegrate, because, in the same way that economic progress destroyed the power of medieval barons, it will destroy the power of the clergy.

Love of neighbor or of God is not criticized by him but it is the business sense which must direct our actions. He assumes that obeying the Divinity is the first rule of moral behavior, but that the measure of that obedience is love is a precept of Christianity, not of nature. It is enough to look at your neighbor as a potential benefactor that sometime may also favor you. As Minowitz observes, both Christianity and AS's sympathetic principle help restrict selfishness but not in the same manner, Christianity fights it in the sphere of action, AS's in the emotional one [25].

"The Catholic Church is seen in AS as an example of a religious institution that played a constructive role in the history of Europe but by maintaining their power for too long it made its contribution history”. Moreover, "when he discusses the role of the Church in the evolution of European universities it is but a part of the long history of the evolution of institutional religion in Europe. This evolution, and the emergence of the liberal Scottish church, made possible the development of the University of Glasgow ${ }^{6}$. Although this is only a chapter in the history of the evolution of mankind it is, however, an instructive and important part because it is where AS draws his principles concerning religion as an institution and his conception of natural religion from, in a way that the religious creed he sees is consistent with the liberal approach” [26].

However, this vision that AS has towards the Catholic Church is a simple example of a greater danger, the danger that the power of a faction that has become official, whether religious, commercial or otherwise, watches only its own interests. That is why, contrary to his friend Hume, he will defend a clear separation between church and state, he will also defend free competition between religious sects, the more there are, the less the risk of it being one that holds all of the power.

The religion that could be proposed according to the strict Smithian principles are the facts provided by natural theology and moral philosophy. The illustrated AS does not accept a different authoritative argument. Also, a good religion is tolerant and rational with other denominations and, either stays out of civil government, or it is submissive to it. That is, an official religion, whichever one it is, does not play an essential role in AS's society and must not be under any control except for what it considers to be the will of God.

\subsection{Human Nature and Individualism in WN}

Although AS was always cautious in regards to explicitly state his beliefs ${ }^{7}$, his doctrine conforms to the deist principles [27]. Some authors explain that his objective is not to present us with an irreligious society but to make religion be entirely secular, to provide a moral service to the commercial society. Thus the "invisible hand" is not theistic, it did not believe that the God of theism controlled the work of the economy, although probably, through janseanist influence he used this metaphor to refer to the practice of a Universal Benevolence. Man does

\footnotetext{
${ }^{6}$ There was an important historical factor that would be good to remember. Despite the union between Scotland and England being established since 1707, it was natural that the Scots would talk about Great Britain, but the British were making the distinction between the two nations. There was a sense of economic and intellectual superiority by the English, who looked at the Scots as an inferior people. This, perhaps, would not only have influenced the perception that Smith had of Oxford, through his personal experience, but also represents, one of the great engines in the formation of this intellectual phenomenon that is the Scottish Enlightenment. The Scots did not only have to learn to speak and write English, eradicating their dialects, but fought to beat the English themselves in the proper use of the language and intellect. To all these inconveniences one was added, which was that the Scots were considered "Jacobites", so they were displaced from political activity after the Glorious Revolution of 1688-1689 that overthrew James II (The Last King of Scotland succession of the Stuarts and Catholic). And so, any association with Catholicism exacerbated even further the anti-Scottish feeling. In the context where AS explains the University of Glasgow also criticizes the University of Oxford for this reason.

${ }^{7}$ Some criticize him because despite Hume in his will leaving his Dialogues for publication he decided not to publish them. In his defense it can be said that in their correspondence David Hume himself, shortly before dying, leaves the issue of the publication of his Dialogues to the discretion of his friend, aware that he was putting him in a difficult situation (cf. Correspondence of Adam Smith (1987) Liberty Press, Indianapolis, 156 and 157, 194-196). Thereupon Hume cautiously decides to leave a copy of his Dialogues to his nephew. Only days after the death of Hume, the 25 August of 1776, Smith wrote to his editor of the WN (and editor of Hume) informing him that he does not wish to participate in the publication of the Dialogues (cf. Correspondence of Adam Smith (1987) Liberty Press, Indianapolis, 172, 211).
} 
not need to be saved by God but to adapt to its design from nature, and if it does, it is possible to expect reward, and otherwise, punishment [28].

As discussed in the previous paragraph, AS does not actually judge that one religion is better than another depending on the type of mediation that it establishes between God and men. He is not interested in the different faiths, by themselves, but only those that confirm what nature shows man as the right thing for his social action, namely, that his behavior has to be oriented to preserve the harmony of society. Religion is useful and tolerable to the extent that it serves to pursue or, at least, not prejudice the public interest. Ultimately this natural religion is simply an ethical behavior. The good effects that will come from this behavior, that to AS is nothing else than following our nature, are the only thing necessary to know if a religion is good or not. In this approach a revelation or a source that gives different moral principles to those from nature is irrelevant.

The Spanish Inquisition censored, as has already been said, the French translation of the WN considering that it induced naturalism. It is clear from the WN that AS defends a natural religion and theology. He expressly says that in the TMS as well which had not yet been translated into Spanish. AS's idea of God is not derived from any religion, but is rather an idea developed from observation and induction, there is no evidence on his system that the supernatural may influence the natural course of things. The possible belief in a Deity has two sources: moral philosophy and natural theology. On the one hand it is possible to believe in a Deity that is Fair Judge who rewards the good and punishes the wicked and on the other, a Deity that is Author of Nature.

The natural things move man and they ultimately will suffice. The Christian law of love is replaced by the precept of nature. Interestingly AS uses Christian values but does not recognize their origin, he does not speak of a religion through revelation or of a personal God. Thus, his impartial spectator is not enough for moral judgment, because it can be wrong. It is the principle of the sense of duty the only one by which the majority of mankind could guide their actions. AS does not wonder about the truth of God's existence, but builds a social organization where the idea of God is consistent with his presuppositions. Religion for him reinforces the moral sense of duty but does not add anything.

"AS's god is not a personal but cosmic god like that of the Stoics, who created nature and order and prescribes general rules. His religion is essentially horizontal, that is, it is a moral reference" [29].

The Enlightenment's crisis is essentially a crisis of authority that virtually all across Europe becomes a faith and trust crisis. The conflict marks a breakdown of ethical balance, a traditional authority crisis, a return to humanistic ideals, of freedom, openness, human universality. "The historical authority crisis becomes a crisis of authority as such in the illustration, a crisis against anything that imposes rules from above or from outside, that make the ethical quality of the individuals depend on those actions from an imperative that is their source (...) Ethic is then conceived as the result of human freedom itself, and therein lies the problem" [30].

Interestingly, in some contrast with the approach of his time, for AS it seems rather that humans are in society not as a result of rational deliberation but rather through a motion instigated by two principles: that of authority and that of utility. Authority is founded on the natural human tendency to adjust to the feelings and wishes of the powerful, while it is simpler to sympathize with joy than with suffering [31]. From his point of view, the principle of authority is above that of utility because the former takes place in all age groups while the second stems from the inequality that need not always be. On one side, other people are necessary in this society in which we live that is commercial and, on the other, they are an opportunity for us to exercise on our virtues.

And yet, despite this vision of a man in need of others naturally, it is easy to fall into individualism. "In Smithian theory, the omission of good is punishable only when it is sanctioned by civil or positive law, that is, when it requires that a particular good is done. Good to others is done, either from morality, or from the jurisprudence: only in the second case it becomes compulsory" [32]. In a society where charity has been replaced by correctness as the criterion that distinguishes the true virtuous man it is easy to fall into individualism.

According to AS, to act strictly based on benevolence is impossible for man. On this point he criticizes both the early Fathers of the Catholic Church as well as some ministers of Cambridge after the Reformation. Man acts only from his nature, so both from benevolence and from pride. This last thing indirectly leads to beneficial effects on others, because when looking after oneself one benefits but also benefits the rest of society. In the development of the anthropocentric, individualistic tendency, of this new man that AS introduces to us, the concept of autarky is vigorously reconquered.

\section{Final Thoughts to Conclude}

While it is true that for a thorough interpretation of the Scottish author, it is necessary to read his works in the 
light of the properties and characteristics that the Enlightenment had, it is not less true that one can risk generalizing these and losing the specifics of our author. AS uses the language and rhetorical discourse typical of his time, of the deism of the Enlightenment that believes in a benevolent God. He seems to be a providentialist deist, he defends as we have already seen, a natural religion and it is clear that he is one of the reasons that the Inquisition's censors had to include it in the Index. But not all authors claim that he was a believer.

"As I have suggested above, although many see Smith as a deist, my personal opinion, and it is only an opinion since there is no evidence, is that he is a practical agnostic. He never denies the existence of God, but when he has to rely on a deistic language, like in TMS, he uses it, whereas when he can avoid the problems resulting from the publication of the Dialogues Concerning Natural Religion by his friend Hume, he avoids them. In my view, his analysis of religions so coldly realistic simply reinforces the thesis of a practical agnosticism” [33].

In any case, it is true that besides the use of deistic language, to AS science is the antidote to the poison of religious enthusiasm and superstition. This leads him to a harsh criticism of the Papacy and the Church of Rome. It is true as well, however, that they are not mainly directed at its creed or doctrine, which to him, are more secondary issues, but rather to the perverse socio-political effects that were carried out in the name of religion, in a time, historically, close to that in which he lives.

He is not part of any religious denomination but the values that he assumes are undoubtedly Christian, he is a man of the Enlightenment, with a Christian tradition and education, which should not be forgotten. It merely describes the fallen nature, but does not call it that, he simply observes its weakness and imperfection, because to AS there is nothing that enables the observation that it is a fallen nature, he does not accept the biblical data or Revelation which is why he defends a natural religion. However selfish that a man may be supposed to be, there are evidently in his nature principles that make him be interested in the fate of others. To pay attention to events that exceed the factuality that is observed falls outside his presuppositions.

Moreover, one can not say that he upholds an extreme liberalism, he is rather an advocate of free trade and of a commercial society, he does not understand freedom as complete autonomy, man needs to develop a number of virtues to live in society [34]. He does not seek an economic theory but rather as a result of observation (lets remember the influence during the Enlightenment of the Newtonian method) he speaks of a realistic system, meaning, it is prescriptive not normative. And yet, in the Catholic tradition he has been identified with a certain individualistic automatism that is not so, or at least, it is not radical even though it is easy to fall into that deduction, when interpreting self-interest as the sole engine and driver of the free market. We can say that, for AS, an economic man is wiser and fairer because he acts for his own interest and with some propriety in his behavior, precisely for this reason, he is not required to be a hero and at the same time, there is a number of social virtues which man has to acquire to prosper and be happy ${ }^{8}$.

What seems clear is that the way of interpreting and translating in Spain at the time, it highlights the contrast between two cultures, the Latin and the Anglo-Saxon. Both the interpretation of A. Smith to the form of government of Spain at the time and the typecasting of the Catholic Church in the Middle Ages, and that of Spanish translators to the Scottish thinker, are products of their time. It is true that the Enlightenment itself, conceives human nature as unchanging, contemptuous of history and subject to iron laws such as those of nature. That is, the Enlightenment might be blind to the difference of cultures because to accept it would be tantamount to the demolition of its conception of human nature. This image of man as pure reasoning would end up being overthrown in the late nineteenth century.

A different matter is the response of the ecclesiastical authorities, both Spanish and not Spanish, in the eighteenth and nineteenth centuries. In this area the encyclical Quanta Cura and the Syllabus of Pius IX from 1864 stands out first, consisting mainly of the conviction of a number of errors resulting from the relativism and deism of the Enlightenment because of their incompatibility with the doctrine of the Church. In Spain the figure of Felix Sardá and Salvany stands out with one of his many books entitled Liberalism is a sin (1887) [35] . They

\footnotetext{
${ }^{8}$ It exceeds the purpose of this paper to analyze the difference between self-interest and selfishness, not only according to A. Smith but based on tradition from before his time. It can be consulted at FORCE, P. (2003) Self-Interest before Adam Smith. A Genealogy of Economic Science, Cambridge University Press, Cambridge.

${ }^{9}$ This work was translated into the main European languages. It was approved and praised by the Roman Congregation of the Index in 1887, praised and recommended by eight bishops, including the one from Barcelona. Praised by Pope Leo XIII who read it personally and his brother Cardinal Pecci. Supported and disseminated by the Jesuits. Felix Sarda y Salvany was born in the industrial town of Sabadell, from a wealthy family (his mother belonged to Latin and Humanities professor in the Barcelona Conciliar Seminary, a graduate in Law and Philosophy. He did numerous works of charity with the family estate he inherited. He defended the Syllabus and undertook campaigns against ideologies contrary to the Catholic faith; and has a memorial dedicated to him in Sabadell, where the whole town went to his funeral, once he passed away.
} 
are not a critique, therefore, to the $\mathrm{WN}$.

For a long time it was thought that capitalism and free markets, by generating inequalities, were contrary to the doctrine of the Church. The magisterium of the Second Vatican Council and the subsequent encyclicals on social issues, especially Centesimus annus, explain in a clear and convincing way the view of the Church on the apparent incompatibility of the free market system with its social doctrine.

In the encyclical Centesimus annus it is developed, more than in earlier ones, the idea that common good contains and needs, to be reached, both from economic and political freedom, both regulated by clear legal rules and by institutions that have been created in order to watch over and preserve their freedom well. When speaking about the supremacy of the common good in the social doctrine of the Church we are not looking for an excuse to dodge the responsibility of the private sector, this has to be protected by the institutions but also institutions need people who relate with others in terms of understanding and participation. On the other hand, the legitimate role of profit as an indication of the good performance of the company is recognized [36].

With these statements, John Paul II abandoned the idea that social doctrine of the Church was a third path between Marxist collectivism and capitalist liberalism, but rather a vision of the role of law was adopted, of the separation of power and of the state referred to the economy according to the best liberal tradition.

The common good is not as many believe it to be a particular product, a particular social pattern or a particular type of distribution of wealth and opportunity, but an institutional framework that is generated as a result of the citizens using their freedom. According to this point of view, institutions and their logical procedures should be recognized with the requirements of justice and charity [37]. The capitalist postulate of laissez-faire is thus seen in the sense of giving economic freedom to citizens and their creativity, in order to have free competition guaranteed by the state and by law. In this regard it should be recalled that the best liberal tradition has always claimed that the binomial state-market should be complemented by other forms of solidarity rooted in civil society.

\section{Acknowledgements}

This paper could not have been written without the help of Prof. Martin Schlag whom I sincerely appreciate his support and cooperation.

\section{References}

[1] Smith, A. (1776) La riqueza de las naciones. F.C. E. México.

[2] Rodríguez Braun, C. (1997) The Theory of Moral Sentiments. Alianza, Madrid, 7.

[3] Fuentes Quintana, E. and Perdices de Blas, L. (1996) Estudio preliminar a la edición facsímil de la traducción de la Riqueza de las Naciones realizada por José Antonio Alonso Ortiz en 1794. Junta de Castilla y León, Valladolid.

[4] Rodríguez Lluesma, C. (1997) Los modales de la pasión. Adam Smith y la sociedad comercial. EUNSA, Pamplona, 16.

[5] Reeder, J. (1978) Economía e ilustración en España, traducciones y traductores, 1717-1800. Moneda y Crédito, 147, 66-68.

[6] Índice General de los Libros Prohibidos (1844) Imprenta de D. Félix Palacios Editor, Madrid, 318.

[7] Schwartz, P. (2000) La recepción inicial de la "Riqueza de las Naciones” en España. In: Quintana, F., Ed., La Economía Clásica, Madrid, 177.

[8] Plaza Prieto, J. (1957) Introducción a la Riqueza de las Naciones en España e Hispanoamérica 1780-1830. Revista de Economía Política, 8, 1199-1214.

[9] Schwartz, P. (2000) La recepción inicial de La Riqueza de las Naciones en España. In: Fuentes Quintana, E., Ed., La Economía Clásica, 171-238.

[10] Perdices de Blas, L. (2003) The Wealth of Nations and Spanish Economists. In: Cheng-Chung, L., Ed., Adam Smith across Nations, Oxford University Press, Oxford, 347-376.

[11] Cabrillo, F. (1978) Traducciones al español de libros de Economía política (1800-1880). Moneda y Crédito, 147, 72.

[12] Perdices de Blas, L. (1990) La riqueza de las naciones y los economistas españoles. Documento de trabajo 9101, Facultad de Ciencias Económicas y Empresariales, Madrid, 36.

[13] Cheng-Chung, L., Ed. (2003) Adam Smith across Nations. Oxford University Press, Oxford.

[14] Smith, A. (1776) La Riqueza de las Naciones. F.C.E., México, 575.

[15] Smith, A. (1776) La Riqueza de las Naciones. F.C.E., México, 600. 
[16] Barucci, P. (1977) Adam Smith e la nascita della scienza económica. Sansoni, Firenze, 110.

[17] Smith, A. (1776) La Riqueza de las Naciones. F.C.E., México, 431.

[18] Smith, A. (1776) La Riqueza de las Naciones. F.C.E., México, 429.

[19] Smith, A. (1776) La Riqueza de las Naciones. F.C.E., México, 721-723.

[20] Smith, A. (1776) La Riqueza de las Naciones. F.C.E., México, 730.

[21] Smith, A. (1776) La Riqueza de las Naciones. F.C.E., México, 732.

[22] Fitzgibbons, A. (1996) Adam Smith's System of Liberty, Wealth and Virtue: The Moral and Political Foundations of The Wealth of Nations. Clarendon Press Oxford, Oxford, 45.

[23] Griswold Jr., C.L. (1999) Adam Smith and the Virtues of Enlightenment. Cambridge University Press, Cambridge, 274.

[24] Smith, A. (1776) La Riqueza de las Naciones. F.C.E., México, 733.

[25] Minowitz, P. (1993) Profits, Priests, and Princes: Adam Smith’s Emancipation of Economics from Politics and Religion. Stanford University Press, Stanford, 229.

[26] Evensky, J. (2005) Adam Smith’s Moral Philosophy: A Historical and Contemporary Perspective on Markets, Law, Ethics, and Culture. Cambridge University Press, New York, 91. http://dx.doi.org/10.1017/CBO9780511610646

[27] Hernández Andreu, J. (2014) Si Keynes fuera ministro de Economía ante la crisis del 2008. Delta Publicaciones, Madrid, 41-50.

[28] Lázaro, R. (2002) La sociedad comercial en Adam Smith. EUNSA, Pamplona, 337.

[29] Rodríguez Braun, C. (1997) La teoría de los sentimientos morales. Alianza, Madrid, 31.

[30] Preti, G. (1957) Alle origine dellética contemporanea. Laterza, Bari, 33.

[31] Smith, A. (1776) La Riqueza de las Naciones. F.C.E., México, Books I and V.

[32] Lázaro, R. (2002) La sociedad comercial en Adam Smith. EUNSA, Pamplona, 244.

[33] Montes, L. (2004) Adam Smith liberal o cristiano? Estudios públicos, Santiago de Chile, 125.

[34] Dermange, F. (2003) Le Dieu du Marché. Éthique, économie et théologie dans l’oeuvre d’Adam Smith. Le Champ Étique 39, Paris.

[35] Sardá y Salvany, F. (1887, 2009) El liberalismo es pecado. Pagés, Lleida.

[36] Paul II, J. (1991) Encyclical. Centesimus annus, 35.

[37] Rhomheimer, M. (2012) Capitalism Economy, Social Justice, and Catholic Social Doctrine: Traditional Misunderstanding and the Genesis of a New Vision of the Role of the State. In: Schlag, M. and Mercado, J.A., Eds., Free Markets and the Culture of Common Good, Springer, New York, 42. 